\title{
Controversy in the Surgical Extent of Parotidectomy, Neck Treatment, and Adjuvant Treatment of Parotid Gland Cancer
}

\author{
Young Min Park (iD \\ Department of Otorhinolaryngology, Yonsei University College of Medicine, Gangnam Severance Hospital, Seoul, Korea
}

\author{
이하선 암 치료에서 이하선 절제술의 범위, 경부 절제술 및 보조 방사선 치료의 적응증 \\ 박영민 \\ 연세대학교 의과대학 이비인후과학교실
}

\author{
Received August 28, 2021 \\ Revised September 14, 2021 \\ Accepted October 26, 2021 \\ Address for correspondence \\ Young Min Park, MD, PhD \\ Department of Otorhinolaryngology, \\ Yonsei University \\ College of Medicine, \\ Gangnam Severance Hospital, \\ 211 Eonju-ro, Gangnam-gu, \\ Seoul 06273, Korea \\ Tel $+82-2-2019-3460$ \\ Fax +82-2-3463-4750 \\ E-mail autumnfe79@yuhs.ac
}

This paper analyzed previous research data to identify the most important issues to be considered during treatment of parotid gland cancer (PGC) and reviewed recent advancements in techniques in parotid surgery. For successful treatment of PGC, a preoperative surgical plan should be designed with consideration of the histologic characteristics and anatomical complexity of the tumor, and the functional and anatomical integrity of the facial nerve should be carefully inspected during surgery and damage to the nerve minimized. The need for adjuvant radiotherapy should be determined based on intraoperative findings and pathologic findings of the specimen after surgery. To optimize treatment outcomes for PGC, the extent of surgery and adjuvant radiotherapy should be decided according to histologic characteristics and risk stratification. Korean J Otorhinolaryngol-Head Neck Surg 2021;64(11):779-84

\section{서 론}

이하선 암(parotoid gland cancer)은 인구 100만 명당 연간 발생 빈도가 6-11건에 불과한 드문 악성 종양이다. ${ }^{1-5)}$ 이하선 암은 조직학적으로 22개의 유형으로 분류할 수 있으며, 가장 흔한 조직학적 유형에는 선양낭성암종(adenoid cystic carcinoma) 점액표피양암종(mucoepidermoid carcinoma), 선방 세포암종(acinic cell carcinoma), 비특이성 선암종(adenocarcinoma not otherwise specified) 등이 있다.,4,6) 조직학적 등 급에 따라서 저악성도 혹은 고악성도 종양으로 구분할 수 있 는데, 저악성도 종양은 일반적으로 양호한 예후를 보이지만 고악성도 종양의 경우 림프절 전이 혹은 원격전이의 발생 위

This is an Open Access article distributed under the terms of the Creative Commons Attribution Non-Commercial License (https://creativecommons.org/licenses/by-nc/4.0) which permits unrestricted non-commercial use, distribution, and reproduction in any medium, provided the original work is properly cited.
험이 높고 불량한 예후를 보인다(Daniele-3). 특히 선양낭성 암종은 신경을 따라서 전파되는 특징이 있기 때문에 필요한 경우 수술 중에 동결절편검사를 활용하여 음성 절제연을 확 인하여야 한다. 또한 안면신경이 이하선 내부로 지나가기 때 문에 수술 전 계획을 수립할 때 악성종양의 신경 침범 가능 성을 살펴야 하며 신경 침범 유무를 수술 중에도 면밀히 확 인하여야 한다.

이하선 암의 적절한 치료를 위해서는 조직학적 유형에 따 른 특징과 해부학적 복잡성을 고려하여 수술 계획을 수립하 여야 하며 질환의 위험도를 바탕으로 보조 치료 시행 여부를 결정해야 한다. 하지만 이하선 암의 적절한 수술 범위와 보조 치료 적응증은 아직까지 명확히 정립되어 있지 않다. 이하선 암의 발생 빈도가 낮고 특정 조직학적 유형별로 충분한 임상 자료가 축적되어 있지 않기 때문에 근거가 높은 무작위 임상 연구를 시행하기 어려운 문제점이 있다. 본 논문은 기존의 
연구 자료들을 분석하여 이하선 암 치료에 있어서 고려되어 야 할 중요 사항들과 아직까지 해결되지 않은 이슈들을 알아 보았다.

\section{이하선 암의 수술 전 치료 계획 수립}

이하선 암의 조직학적 유형을 파악하기 위하여 세포학적 검사가 많이 이용되고 있지만 민감도와 정확성이 낮은 문제점 을 가지고 있다. ${ }^{8,9)}$ 또한, 이하선 종양 병기 설정에 중요한 일부 소견은 수술 중에만 확인할 수 있거나 수술 후 검체의 병리 검사를 통해서만 확인할 수 있다. ${ }^{10,11)}$ 따라서 수술 전 치료 계 획의 설정이 불충분한 정보를 기반으로 이루어질 수밖에 없 으며 수술 시행 이후 종양 병기가 상향되거나 치료 계획이 바 뀌는 경우를 임상에서 흔히 겪을 수 있다. 수술 전 이하선 종 양의 진단에 세침 흡인 검사가 흔히 사용되어 있으나 최근에 는 중심부 바늘 생검 방법의 정확성과 안정성이 보고되었다. ${ }^{12)}$ 중심부 바늘 생검은 기존의 세침 흡인 검사와 비교하여 우월 한 진단 정확성, 민감도, 특이도를 보이고 동반된 합병증의 발 생이 드물지만 이를 수행하기 위해서는 잘 훈련된 의사와 시 설이 준비되어야 하고, 악성 종양일 경우 종양이 파종될 위험 성을 내포하고 있다는 문제점도 가지고 있다. ${ }^{12)}$

\section{이하선 절제술}

\section{이하선 절제술의 범위}

종양의 범위와 종양에 의하여 침습된 주변 구조물들을 고 려하여 수술의 범위가 정해지며 다양한 범위의 이하선 절제 술을 시행할 수 있다. ${ }^{13)}$ 부분 이하선 절제술은 종양과 주위의 정상조직을 포함하여 이하선 천엽의 일부를 절제하는 경우이 다. 이하선 천엽 절제술은 안면신경을 기준으로 이하선 천엽 을 전부 제거하는 경우이다. 이하선 전 절제술은 이하선의 모 든 실질을 제거하는 경우이다. 근치적 이하선 절제술은 안면 신경을 동반하여 절제하는 경우이다. 확장된 근치적 이하선 절제술(extended radical parotidectomy)은 다음의 구조물들 중에서 하나를 같이 제거하는 경우이다(skin, mastoid, mandible, masticatory muscles, infratemporal fossa).

고악성도 종양 혹은 진행된 병기의 종양의 경우 적어도 이 하선 전 절제술을 시행하여야 하지만, 이하선 천엽에 위치한 작은 크기(T1-2) 종양의 경우 적절한 수술 범위에 대해서 논 란이 존재한다. 저악성도 T1-2 이하선 암의 경우 부분 이하 선 절제술 시행으로도 우수한 종양학적 결과들이 보고되었 다. ${ }^{14,15)}$ 하지만 이하선 내 림프절 전이 위험을 고려하여 저악성 도 이하선 암에서도 이하선 전 절제술을 시행하여야 한다고
주장한 연구들도 존재한다. ${ }^{13,16-20)}$ Klussmann 등 ${ }^{21)}$ 이 보고한 바에 의하면 저악성도와 고악성도 종양에서 림프절 전이 발 생 비율이 각각 $22 \%$ 와 $49 \%$ 였다. 림프절 전이가 있었던 환자 들에서 이하선 내 림프절 전이를 동반하였던 경우는 $25 \%$ 였 고 경부 림프절 전이만 있었던 경우가 $7.5 \%$ 였다. 따라서 해당 저자들은 원발부위와 림프절 전이를 줄이기 위하여 모든 이 하선 암 환자에서 최소한 이하선 전 절제술을 시행할 것을 권 고하였지만 저악성도 이하선 암에서 이하선 절제술의 범위에 대해서는 아직까지 많은 논란이 존재한다. 수술 전에 양성 종 양으로 오인되어 피막 외 절제술(extracapsular dissection)을 시행하였던 환자들의 종양학적 결과를 분석한 연구에 따르 면, 저악성도 이하선 암의 경우 전통적인 이하선 천엽 혹은 전 절제술을 시행한 경우와 비교하여 환자들의 생존율과 치 료 후 삶의 질에 있어서 유의미한 차이를 보이지 않았다. 하 지만 이하선 암종에서 피막 외 절제술의 종양학적 그리고 기 능적 결과에 대해서는 추가적인 검증이 필요하며, 해당 환자 들에서 추가적인 수술 혹은 방사선 치료 유무에 대해서도 추 가적인 연구가 필요한 상황이다. ${ }^{22)}$

\section{안면신경에 대한 수술적 처치}

이하선 암 수술에 있어서 안면신경의 처치는 중요한 고려 사항이다. 종양이 안면신경에 가까이 위치하거나 인접해 있 지만 정상적으로 신경 기능이 유지되어 있을 때는 신경의 해 부학적 그리고 기능적으로 보존하기 위하여 모든 노력을 기 울어야 한다. 이 때에 육안적으로 잔존 종양을 남기지 않도 록 하여야 하며, 미세 종양 조직 같은 경우 수술 이후 방사선 보조 치료 등을 사용하여 효과적으로 처리할 수 있다.,13) 종 양에 의하여 신경이 완전히 둘러 쌓인 경우 혹은 수술 전에 안면 신경 기능이 손상된 경우는 종양과 함께 신경을 희생 하여야 한다. ${ }^{5,13)}$

\section{이하선 암의 잠재적 경부 림프절 전이}

치료적 경부 림프절 절제술을 시행 받은 림프절 전이를 동 반한 이하선 암 환자에서 광범위한 림프절 전이를 병리검사 에서 확인할 수 있기 때문에 이러한 경우 level I-V를 포함하 는 포괄적인 경부 림프절 절제술(comprehensive neck dissection)을 시행하여야 한다. 하지만 림프절 전이를 동반하지 않은(cNO) 이하선 암에서 경부 치료에 대해서는 여러 논란들 이 있다. ${ }^{21)}$ 이하선 암의 잠재적인 림프절 전이(occult nodal metastasis)의 발생 비율은 $12 \%-49 \%$ 로 알려져 있다. ${ }^{21-27)}$ 특 히 고악성도 종양, 진행된 병기, 고령, perilymphatic invasion, desmoplastic features 소견이 있는 경우 잠재적인 림프 
절 전이 위험이 높기 때문에 예방적 림프절 절제술(elective neck dissection) 시행을 권고하고 있다. ${ }^{26-28)}$ 그렇지만 $\mathrm{cN} 0$ 이하선 암에서 예방적 림프절 절제술의 적응증과 적절한 수 술 범위는 아직 확립되어 있지 않다. ${ }^{29)}$

기존 연구에서 예방적 림프절 절제술을 시행한 환자들이 경과 관찰을 시행한 환자들과 비교하여 우월한 결과를 보였 지만 해당 연구에서는 수술 후 보조 방사선 치료의 효과가 고려되지 않았기 때문에 결과 해석에 주의하여야 한다. ${ }^{25)}$ 경 부 레벨에 따른 잠재적 림프절 전이 발생 비율을 분석한 연 구들에 의하면 이하선 암은 level 2-3에 대해서 상대적으로 높은 잠재적 전이 비율을 보인다. ${ }^{30-33)}$ 나머지 경부 레벨에 대 해서는 잠재적 림프절 전이가 드물게 발생하는 것으로 알려졌 다. 선택적인 이하선 암 환자에서 level 2-3를 포함하는 super-selective neck dissection을 시행할 수 있으며 수술 후 병리검사 결과를 바탕으로 수술 후 보조 방사선 치료 시행 여부를 고려할 수 있다. ${ }^{34,35)} \mathrm{cNO}$ 이하선 암 환자에서 예방적 림프절 절제술를 대신해서 예방적 방사선 치료를 시행하는 것도 하나의 대안이 될 수도 있다. ${ }^{36)}$ 특히, 수술 이후 보조 방 사선 치료가 예정되어 있는 경우에 경부 림프절 절제술 대신 에 방사선 치료을 시행하는 것이 적절할 수 있다. ${ }^{36)}$

\section{이하선 내 림프절 전이}

발생기간 동안 이하선의 encapsulation이 일어나기 전에 경 부의 림프계가 형성되기 때문에 이하선 내부에는 림프절들이 존재하며 이를 이하선 내 림프절(IPLNs)라고 한다. ${ }^{16-18,37)}$ 이 하선 천엽에 대략 0-22개의 림프절들이 분포되어 있고, 심엽 에는 0-4개의 림프절들이 분포되어 있다. ${ }^{16-18,37)}$ IPLNs 전이가 이하선 암의 불량한 예후인자로 알려져 있지만 심엽 림프절 전이가 천엽 림프절 전이와 비교하여 보다 불량한 예후를 보 이는지는 명확치 않다. ${ }^{38-41)}$ 실제 많은 이하선 암 환자들에서 는 IPLNs 전이가 없는 경우도 흔하고 천엽 림프절 전이가 있 는 경우에도 심엽 림프절 없이 상경부 림프절로 전이가 일어 나는 경우를 쉽게 볼 수 있다.

피부 상피세포암(cutaneous squamous cell carcinoma)에서 IPLNs 전이는 기타 다른 경부 림프절 전이 유무에 상관없이 환자들의 불량한 치료 결과와 연관된 독립된 예후인자이다. ${ }^{42)}$ 기존 TNM staging에 반영되어 있지 않지만 N classification 을 parotid ( $\mathrm{p}$ classification)와 cervical disease ( $\mathrm{N}$ classification)로 구분할 경우 staging system의 생존 예측 정도가 향상된다고 보고되었다. 이하선 암을 대상으로 한 선행 연구 에서도 p classification이 $\mathrm{N}$ classification와 상관없이 질환의 재발과 연관된 독립된 예후인자로 보고되었고, TNM stating system에 반영할 경우 환자들의 생존 예측 정도를 향상시키 는 것으로 보고되었다. ${ }^{43)}$

\section{이하선 암의 재건 수술}

안면신경, 피부, 뼈 등을 침범한 이하선 암의 경우 광범위 절제 이후에 재건 수술을 동반하여 시행하여야 한다. 제한된 피부 결손을 동반한 경우 primary closure 혹은 cervicofacial rotation flaps 등을 사용하여 재건을 시행할 수 있다. 큰 피부 결손을 동반한 경우 occipital 혹은 postauricular artery perforators를 기반으로 하는 island flaps를 사용할 수 있다. ${ }^{44}$ 큰 피부 결손이 있을 경우 사용 가능한 대안으로 supraclavicular island flap을 사용할 수 있다. ${ }^{45}$ 재건을 위하여 composite flaps가 필요한 경우 피부와 함께 충분한 연부조직을 제공할 수 있는 pedicled flap으로써 pectoralis major myocutaneous and pedicled latissimus dorsi flap을 사용할 수 있다. 일반적으로 이러한 경우에 미세혈관 유리 조직 피판이 선호되고 있으며 anterolateral thigh perforator flap이 가장 흔하게 사용된다. Mandibular defect를 동반하는 경우 osteocutaneous fibular flap을 사용하여 뼈와 피부 결손을 함 께 재건할 수 있다. ${ }^{46}$

\section{안면신경 재건술}

안면신경을 희생하는 경우 immediate cable graft와 static measures를 병행하여 시행하는 것이 최적의 결과를 보인다. ${ }^{47)}$ Greater auricular nerve는 같은 수술 범위 안에서 찾을 수 있으며 cervical plexus의 근위부까지 채취할 수 있기 때문에 이상적인 공여 신경이다. 또한 greater auricular nerve는 안면 신경의 직경이 비슷하고 안면신경과 동일한 monofascicular structure로 이루어진 장점을 가지고 있다. ${ }^{47)}$ Sural nerve를 사 용할 수도 있지만 안면신경와는 다르게 polyfascicular structure이고 같은 수술 범위 안에서 찾을 수 없는 단점을 가지고 있다. ${ }^{47)}$ Cable graft 시행 후 성공적인 reinnervation을 위해 서는 tension-free epineural anastomoses가 반드시 시행되 어야 한다. ${ }^{48)}$ Cable graft가 성공적으로 이루어질 경우 House Brackman grade II or III 정도의 기능 회복을 기대할 수 있 다. ${ }^{48-50)}$ Reinnervation의 electromyography sign은 4.5 개월 이후에 관찰할 수 있으며 근육의 움직임은 6개월 이후에 관 찰할 수 있다. 수술 후 시행되는 보조 방사선 요법이 nerve reinnervation에 영향을 미치지는 않는다. 
Korean J Otorhinolaryngol-Head Neck Surg I 2021;64(11):779-84

Table 1. Multivariate Cox regression analysis for disease-free, distant metastasis-free, and overall survival on various factors

\begin{tabular}{|c|c|c|c|c|c|c|c|c|c|}
\hline \multirow{2}{*}{ Variables } & \multicolumn{3}{|c|}{ Disease-free survival } & \multicolumn{3}{|c|}{ Distant metastasis-free survival } & \multicolumn{3}{|c|}{ Overall survival } \\
\hline & $\mathrm{HR}$ & $95 \% \mathrm{Cl}$ & p-value & $\mathrm{HR}$ & $95 \% \mathrm{Cl}$ & p-value & $\mathrm{HR}$ & $95 \% \mathrm{Cl}$ & $p$-value \\
\hline FN palsy & 0.280 & $0.063-1.252$ & 0.096 & 0.205 & $0.026-1.593$ & 0.130 & & & \\
\hline LVI & 2.687 & $0.999-7.233$ & 0.050 & 5.973 & $1.738-20.530$ & 0.005 & 7.031 & $1.980-24.969$ & 0.003 \\
\hline $\mathrm{PNI}$ & & & & & & & 0.318 & $0.087-1.164$ & 0.083 \\
\hline LN metastasis & & & & 4.752 & $0.969-23.316$ & 0.050 & 2.976 & $0.882-10.036$ & 0.079 \\
\hline ECS & 2.379 & $0.887-6.386$ & 0.085 & & & & & & \\
\hline
\end{tabular}

HR, hazard ratio; $\mathrm{Cl}$, confidence interval; FN, facial nerve; LVI, lymphovascular invasion; PNI, perineural invasion; LN, lymph node; ECS, extracapsular spread

\section{고악성도 이하선암 치료의 경험}

침샘암은 22개의 조직학적 아형들이 포함된 이질적인 질환 이기 때문에 특정 조직학적 아형에만 국한된 임상적 연구를 수행하는 것이 쉽지 않다. ${ }^{51)}$ 저악성도 침샘암의 경우 온순한 양상을 보이면서 수술 혹은 방사선 치료를 포함한 표준 치료 에 대한 반응이 양호하지만 고악성도 침샘암의 경우 병의 초 기에도 전신 전이를 보이는 등 공격적인 양상을 보이기 때문 에 치료에도 불구하고 환자들의 예후는 극히 불량하다. ${ }^{52,53)}$ 본 기관에서 치료받은 고악성도 이하선 암만을 대상으로 분 석을 시행하여, 치료 가능성이 높은 T1-2 고악성도 이하선 암 환자들의 치료 결과와 주요한 치료 실패 요인, 그와 관련된 예 후 인자들을 알아보았다.

62 명의 환자가 고악성도의 이하선 암으로 수술을 시행 받 았고 수술 전 안면마비를 동반하고 있었던 경우는 8건 있었으 며, 23명의 환자가 수술 중 안면신경을 절제하였고 이 중에서 16 명의 환자는 안면신경 재건을 위해 cable graft를 시행 받 았다. 20 명의 환자는 경부절제술을 시행 받지 않았으며 나머 지 34 명의 환자는 경부절제술을 시행 받았다. 수술 후 12 명의 환자는 추가적인 치료를 시행 받지 않았고, 나머지 50명의 환 자는 추가적인 치료를 시행 받았다. 28 명의 환자는 방사선 치 료만 추가로 시행 받았으며 22명의 환자는 항암방사선 치료를 추가로 시행 받았다. TNM stage상에서 stage I 14명, stage II 17 명, stage III 6명, stage IV 25명이었다. 63개월의 평균 추적 관찰 기간 동안 총 25 건의 재발이 발생하였고 local recurrence가 9건, regional recurrence가 0건, 그리고 원격전이가 16 건 있었다. 초 치료를 받은 이후 질환의 재발까지 평균 기 간은 17.0 개월(range, $6-47)$ 이었다. 총 16 명의 환자가 질병으 로 인하여 사망하였다. 5년 전체 생존율은 $73.0 \%$ 였으며 5년 무병 생존율은 $57.6 \%$ 였다.

다변량 Cox proportional regression 분석상 lymphovascular invasion (LVI) 유무만이 질환의 재발 및 환자들의 사망 과 관련하여 유의미한 상관성을 보였다. LVI 유무에 따른 환 자들의 전체 생존율과 무병 생존률을 Kaplan-Meier meth-
$\mathrm{Od}$ 를 통해 분석하였더니 LVI를 보인 환자군에서 유의미하게 전체 생존율과 무병 생존률이 저하되는 것을 확인하였다. 대 부분 사망 원인은 원격전이로 인한 질환의 진행으로 사망하 였다. 다변량 분석을 통하여 원격전이의 발생과 관련이 있는 임상병리적 인자를 찾아보았다. 여러가지 인자들 중에서 LVI 와 lymph node (LN) metastasis 유무가 통계적으로 의미 있 는 상관성을 보였다(Table 1). 위의 두 가지 위험 인자를 가지 지 않은 T1-2 HGPGC 환자의 경우 적절한 표준 치료로서 우 수한 치료 성적을 보이는 것을 확인하였다. 고악성도의 이하선 암은 수술과 방사선 치료를 포함한 적절한 치료에도 불구하 고 예후가 좋지 않으며, 추적 관찰 기간 동안 발생하는 원격 전이가 주된 치료의 실패 요인으로 작용한다. 하지만 이들 환 자 중에서 LVI와 LN metastasis를 보이지 않은 환자들은 기 존의 표준 치료를 통해 우수한 치료 성과를 기대할 수 있다.

\section{결 론}

이하선 암의 성공적인 치료를 위해서는 해당 암종의 조직 학적 특징 및 해부학적 복잡성을 고려한 수술 계획이 이루어 져야 하며, 수술 중 종양에 의한 안면신경 침범 유무를 면밀 히 살펴 불충분한 종양의 절제가 이루어지거나 안면신경에 가해질 수 있는 손상을 최소화하여야 한다. 수술 중 안면신경 침범 유무 혹은 수술 후 검체의 병리검사를 통하여 획득한 정보를 바탕으로 추가적인 방사선 치료를 유무를 결정하여야 될 것이다.

\section{Acknowledgments}

None.

\section{ORCID}

Young Min Park https://orcid.org/0000-0002-7593-8461

\section{REFERENCES}

1) Wahlberg P, Anderson H, Biörklund A, Möller T, Perfekt R. Carcinoma of the parotid and submandibular glands--a study of survival in 2465 patients. Oral Oncol 2002;38(7):706-13. 
2) Terhaard CH, Lubsen H, Van der Tweel I, Hilgers FJ, Eijkenboom WM, Marres HA, et al. Salivary gland carcinoma: Independent prognostic factors for locoregional control, distant metastases, and overall survival: Results of the Dutch head and neck oncology cooperative group. Head Neck 2004;26(8):681-92; discussion 692-3.

3) Luukkaa H, Klemi P, Leivo I, Koivunen P, Laranne J, Mäkitie A, et al. Salivary gland cancer in Finland 1991--96: An evaluation of 237 cases. Acta Otolaryngol 2005;125(2):207-14.

4) Bjørndal K, Krogdahl A, Therkildsen MH, Overgaard J, Johansen J, Kristensen CA, et al. Salivary gland carcinoma in Denmark 19902005: A national study of incidence, site and histology. Results of the Danish Head and Neck Cancer Group (DAHANCA). Oral Oncol 2011;47(7):677-82.

5) Vander Poorten V, Bradley PJ, Takes RP, Rinaldo A, Woolgar JA, Ferlito A. Diagnosis and management of parotid carcinoma with a special focus on recent advances in molecular biology. Head Neck 2012;34(3):429-40.

6) Bradley PJ, McGurk M. Incidence of salivary gland neoplasms in a defined UK population. Br J Oral Maxillofac Surg 2013;51(5):399403.

7) Deschler DG, Eisele DW. Surgery for primary malignant parotid neoplasms. Adv Otorhinolaryngol 2016;78:83-94.

8) Zbären P, Schär C, Hotz MA, Loosli H. Value of fine-needle aspiration cytology of parotid gland masses. Laryngoscope 2001; 111(11 Pt 1):1989-92.

9) Schmidt RL, Hunt JP, Hall BJ, Wilson AR, Layfield LJ. A systematic review and meta-analysis of the diagnostic accuracy of frozen section for parotid gland lesions. Am J Clin Pathol 2011;136(5):72938.

10) Spiro JD, Spiro RH. Cancer of the parotid gland: Role of 7 th nerve preservation. World J Surg 2003;27(7):863-7.

11) Magnano M, Gervasio CF, Cravero L, Machetta G, Lerda W, Beltramo G, et al. Treatment of malignant neoplasms of the parotid gland. Otolaryngol Head Neck Surg 1999;121(5):627-32.

12) Cengiz AB, Tansuker HD, Gul R, Emre F, Demirbas T, Oktay MF. Comparison of preoperative diagnostic accuracy of fine needle aspiration and core needle biopsy in parotid gland neoplasms. Eur Arch Otorhinolaryngol 2021;278(10):4067-74.

13) Cracchiolo JR, Shaha AR. Parotidectomy for parotid cancer. Otolaryngol Clin North Am 2016;49(2):415-24.

14) Lim YC, Lee SY, Kim K, Lee JS, Koo BS, Shin HA, et al. Conservative parotidectomy for the treatment of parotid cancers. Oral Oncol 2005;41(10):1021-7.

15) Park YM, Yoon SO, Koh YW, Kim SH, Lim JY, Choi EC. Clinicalpathological prognostic factors and treatment failure patterns in T1-2 high-grade parotid gland cancer. Oral Oncol 2020;110:104884.

16) McKean ME, Lee K, McGregor IA. The distribution of lymph nodes in and around the parotid gland: An anatomical study. Br J Plast Surg 1985;38(1):1-5.

17) Garatea-Crelgo J, Gay-Escoda C, Bermejo B, Buenechea-Imaz R. Morphological study of the parotid lymph nodes. J Craniomaxillofac Surg 1993;21(5):207-9.

18) Pisani P, Ramponi A, Pia F. The deep parotid lymph nodes: An anatomical and oncological study. J Laryngol Otol 1996;110(2):14850 .

19) Olsen SM, Moore EJ, Koch CA, Kasperbauer JL, Olsen KD. Oral cavity and oropharynx squamous cell carcinoma with metastasis to the parotid lymph nodes. Oral Oncol 2011;47(2):142-4

20) Olsen KD, Quer M, de Bree R, Vander Poorten V, Rinaldo A, Ferlito A. Deep lobe parotidectomy-why, when, and how? Eur Arch Otorhinolaryngol 2017;274(12):4073-8.

21) Klussmann JP, Ponert T, Mueller RP, Dienes HP, Guntinas-Lichius O. Patterns of lymph node spread and its influence on outcome in resectable parotid cancer. Eur J Surg Oncol 2008;34(8):932-7.
22) Mantsopoulos K, Velegrakis S, Iro H. Unexpected detection of parotid gland malignancy during primary extracapsular dissection. Otolaryngol Head Neck Surg 2015;152(6):1042-7.

23) Nobis CP, Rohleder NH, Wolff KD, Wagenpfeil S, Scherer EQ, Kesting MR. Head and neck salivary gland carcinomas--elective neck dissection, yes or no? J Oral Maxillofac Surg 2014;72(1):20510.

24) Armstrong JG, Harrison LB, Thaler HT, Friedlander-Klar H, Fass $\mathrm{DE}$, Zelefsky MJ, et al. The indications for elective treatment of the neck in cancer of the major salivary glands. Cancer 1992;69(3):615-9.

25) Zbären P, Schüpbach J, Nuyens M, Stauffer E. Elective neck dissection versus observation in primary parotid carcinoma. Otolaryngol Head Neck Surg 2005;132(3):387-91.

26) Stennert E, Kisner D, Jungehuelsing M, Guntinas-Lichius O, Schröder U, Eckel HE, et al. High incidence of lymph node metastasis in major salivary gland cancer. Arch Otolaryngol Head Neck Surg 2003;129(7):720-3.

27) Kawata R, Koutetsu L, Yoshimura K, Nishikawa S, Takenaka H. Indication for elective neck dissection for $\mathrm{N} 0$ carcinoma of the parotid gland: A single institution's 20-year experience. Acta Otolaryngol 2010;130(2):286-92.

28) Borsetto D, Iocca O, De Virgilio A, Boscolo-Rizzo P, Phillips V, Nicolai $P$, et al. Elective neck dissection in primary parotid carcinomas: A systematic review and meta-analysis. J Oral Pathol Med 2021;50(2):136-44.

29) Gould EA, Winship T, Philbin PH, Kerr HH. Observations on a "sentinel node" in cancer of the parotid. Cancer 1960;13:77-8.

30) Lim CM, Gilbert M, Johnson JT, Kim S. Is level V neck dissection necessary in primary parotid cancer? Laryngoscope 2015;125(1): $118-21$.

31) Lau VH, Aouad R, Farwell DG, Donald PJ, Chen AM. Patterns of nodal involvement for clinically N0 salivary gland carcinoma: Refining the role of elective neck irradiation. Head Neck 2014;36(10): 1435-9.

32) Ali S, Palmer FL, DiLorenzo M, Shah JP, Patel SG, Ganly I. Treatment of the neck in carcinoma of the parotid gland. Ann Surg Oncol 2014;21(9):3042-8.

33) Weiss MH, Harrison LB, Isaacs RS. Use of decision analysis in planning a management strategy for the stage N0 neck. Arch Otolaryngol Head Neck Surg 1994;120(7):699-702.

34) Pan $W, B a K$, Niu $X$, Liu F, Fang Q. Sentinel lymph node biopsy in cN0 neck management of parotid cancer. Sci Rep 2019;9(1):8339.

35) Warshavsky A, Rosen R, Muhanna N, Ungar O, Nard-Carmel N, Abergel A, et al. Rate of occult neck nodal metastasis in parotid cancer: A meta-analysis. Ann Surg Oncol 2021;28(7):3664-71.

36) Chen AM, Garcia J, Lee NY, Bucci MK, Eisele DW. Patterns of nodal relapse after surgery and postoperative radiation therapy for carcinomas of the major and minor salivary glands: What is the role of elective neck irradiation? Int J Radiat Oncol Biol Phys 2007; 67(4):988-94.

37) Sönmez Ergün S, Gayretli O, Büyükpınarbaşılı N, Yıldız K, Gürses IA, Avşar A, et al. Determining the number of intraparotid lymph nodes: Postmortem examination. J Craniomaxillofac Surg 2014;42(5):657-60.

38) Guntinas-Lichius O, Thielker J, Robbins KT, Olsen KD, Shaha AR, Mäkitie AA, et al. Prognostic role of intraparotid lymph node metastasis in primary parotid cancer: Systematic review. Head Neck 2021;43(3):997-1008.

39) Boahene DK, Olsen KD, Lewis JE, Pinheiro AD, Pankratz VS, Bagniewski SM. Mucoepidermoid carcinoma of the parotid gland: The Mayo clinic experience. Arch Otolaryngol Head Neck Surg 2004;130(7):849-56.

40) Lim CM, Gilbert MR, Johnson JT, Kim S. Clinical significance of intraparotid lymph node metastasis in primary parotid cancer. Head 
Neck 2014;36(11):1634-7.

41) Feng Y, Liu F, Cheng G, Fang Q, Niu X, He W. Significance of intraparotid node metastasis in predicting local control in primary parotid cancer. Laryngoscope 2019;129(10):2309-12.

42) O’Brien CJ, McNeil EB, McMahon JD, Pathak I, Lauer CS, Jackson MA. Significance of clinical stage, extent of surgery, and pathologic findings in metastatic cutaneous squamous carcinoma of the parotid gland. Head Neck 2002;24(5):417-22.

43) Wu J, Fang Q, Liu F, Zhang X. Intraparotid node metastases in adults with parotid mucoepidermoid cancer: An indicator of prognosis? Br J Oral Maxillofac Surg 2020;58(5):525-9.

44) Behan FC, Lo CH, Sizeland A, Pham T, Findlay M. Keystone island flap reconstruction of parotid defects. Plast Reconstr Surg 2012;130(1):36e-41e.

45) Emerick KS, Herr MW, Lin DT, Santos F, Deschler DG. Supraclavicular artery island flap for reconstruction of complex parotidectomy, lateral skull base, and total auriculectomy defects. JAMA Otolaryngol Head Neck Surg 2014;140(9):861-6.

46) Jones NF, Vögelin E, Markowitz BL, Watson JP. Reconstruction of composite through-and-through mandibular defects with a doubleskin paddle fibular osteocutaneous flap. Plast Reconstr Surg 2003;112(3):758-65.
47) Reddy PG, Arden RL, Mathog RH. Facial nerve rehabilitation after radical parotidectomy. Laryngoscope 1999;109(6):894-9.

48) Guntinas-Lichius $O$. The facial nerve in the presence of a head and neck neoplasm: Assessment and outcome after surgical management. Curr Opin Otolaryngol Head Neck Surg 2004;12(2):133-41.

49) Lee MC, Kim DH, Jeon YR, Rah DK, Lew DH, Choi EC, et al. Functional outcomes of multiple sural nerve grafts for facial nerve defects after tumor-ablative surgery. Arch Plast Surg 2015;42(4):461-8.

50) House JW, Brackmann DE. Facial nerve grading system. Otolaryngol Head Neck Surg 1985;93(2):146-7.

51) Seethala RR, Stenman G. Update from the 4th edition of the World Health Organization classification of head and neck tumours: Tumors of the salivary gland. Head Neck Pathol 2017;11(1):55-67.

52) Johnston ML, Huang SH, Waldron JN, Atenafu EG, Chan K, Cummings BJ, et al. Salivary duct carcinoma: Treatment, outcomes, and patterns of failure. Head Neck 2016;38 Suppl 1:E820-6.

53) Jayaprakash V, Merzianu M, Warren GW, Arshad H, Hicks WL Jr, Rigual NR, et al. Survival rates and prognostic factors for infiltrating salivary duct carcinoma: Analysis of 228 cases from the surveillance, epidemiology, and end results database. Head Neck 2014;36(5):694701.

\section{정답 및 해설}

(5)

성인 여자 환자에서 주로 일측성 중이염을 호소하며, 비인두내시경 검진에서 궤양성 또는 whitish patch 양상을 보이고, 사 진과 같이 이관 주위나 비중격 후방을 침범하는 비인두 결핵 증례이다. 조직검사에서 괴사를 동반한 만성 육아종성 염증 소견을 보였으며, TB-PCR 결과 양성이었다.

참고 문헌: Lee CJ, Choi YH, Jeon ES, Lee DH. Six cases of nasal cavity and nasopharyngeal tuberculosis. Korean J Otorhinolaryngol-Head Neck Surg 2013;56(12):795-9.

Cho YS, Choi N, Kim HY. A two cases of primary tuberculosis at the nasopharynx. J Rhinol 2015;22(2):123-7. 